\title{
Koncept Standardů společného základu ve Spojených státech amerických: výuka čtení v primárním vzdělávání ${ }^{1}$
}

\author{
Pavla Sýkorová \\ Masarykova univerzita, Pedagogická fakulta, Institut výzkumu školního vzdělávání
}

Redakci zasláno 31. 3. 2015 / upravená verze obdržena 5. 2. 2016 /

k uveřejnění přijato 6. 2. 2016

\begin{abstract}
Abstrakt: Cílem tohoto článku, který se pohybuje na pomezí přehledové a teoretické studie, je představit čtenáři kurikulární dokument Standardy společného základu Spojených států amerických (Common core state standards). První cást kapitoly přibližuje pojetí Standardu společného základu napříč celým školním vzděláváním. Další pasáže jsou věnovány analýze standardů pro vzdělávací oblast anglický jazyk se zaměřením na závěrečné výstupy jednotlivých ročníků koncipovaných pro výuku čtení, blíže prezentují standardy zacílené na čtvrtý ročník primární školy a nabízí komparativní pohled výuky čtení ve Standardech společného základu a v Rámcovém vzdělávacím programu pro základní vzdělávání. Studie naznačuje rozdílnosti v závěrečných výstupech pro výuku čtení na základní škole, v nichž bylo např. zjištěno, že české kurikulum oproti americkému plně neakceptuje esteticko-výchovnou složku literatury.
\end{abstract}

Klíčová slova: Common core state standards, Standardy společného základu, kurikulum Spojených států amerických, výuka čtení, RVP ZV

Spojené státy americké tvoří padesát států a jeden federální distrikt. Idea vzniku kurikulárního dokumentu vzdělávání, který by byl platný ve všech státech, se zdála být zpočátku poněkud utopická vzhledem k multikulturním, sociálním a ekonomickým rozdílům jednotlivých států. I přes určitou prvotní skepsi lze ve Spojených státech amerických již od začátku devadesátých let minulého století vysledovat snahu o vytvoření společného základu vzdělávání v oblasti anglického jazyka a matematiky, která později v roce 2009 vedla $\mathrm{k}$ vytvoření Standardů společného základu ${ }^{2}$ (Common core state standards).

1 Kapitola vznikla za podpory projektu KUME 2015: Kurikulum základní školy: metodologické př́stupy a empirická zjištění (MUNI/A/1360/2014).

2 Záměrně bylo z originálního názvu vypuštěno slova „státní“ (state). Autorka se domnívá, že pro účely tohoto textu ztrácí na významu. $V$ jiném českém překladu bývá označení uváděno jako Společné základní standardy (NÚV, 2014). 
Motivace k napsání článku, který se pohybuje na rozhraní teoretické a přehledové studie, vychází z realizovaného mezinárodního výzkumu autorky zabývajícího se čtenářstvím českých a amerických žáků čtvrtého ročníku základní školy. ${ }^{3}$ Autorka příspěvku si klade za cíl vykreslit koncepci a obsah Standardů společného základu Spojených států amerických (doposud nepředstaven české odborné veřejnosti) a upozornit na jeho gramotnostní pojetí. ${ }^{4}$ Studie přibližuje standardy pro vzdělávací oblast anglického jazyka se zaměřením na vyučování čtení a prezentuje výstupy adresované jednotlivým ročníkům primárního vzdělávání (elementary school). Ty dává do souvislosti s platným českým kurikulem. V roce 2013 vzešly v platnost (mj.) Standardy pro základní vzdělávání - Český jazyk a literatura. Studie má poukázat na některé opomíjené skutečnosti spojené právě se zaváděním tohoto standardu do RVP ZV (2013; srov. Rusek, 2015).

Common core state standards (dále jen Standardy společného základu či CCSS) stále vyvolávají ve Spojených státech amerických vlnu rozporuplných reakcí. Zatímco jedna část odborníků je považuje za nečekaný útok na práva jednotlivých států v souvislosti s rrízenou kontrolou práce vzdělávacích institucí ze strany vládních orgánů, jiná tvrdí, že se jedná o pečlivě promyšlenou a několik let připravovanou reformu, která se $\mathrm{v}$ USA začínala projevovat již v devadesátých letech minulého století. ${ }^{5}$ Právě v tomto období, kdy započala myšlenka vytvoření standardů veřejného vzdělávání pomocí federálního zásahu, se objevily i první výzvy pro oponenty k vyjádření nesouhlasu s jejich zavedením.

3 Šetření probíhalo ve spolupráci s pracovištěm Graduate School of Education, University of California, Berkeley.

$4 \quad$ V této souvislosti je nutno ukotvit terminologické pozadí prezentované problematiky, a to především pojmů čtenářská gramotnost, čtenářská kompetence a čtení, tak jak je chápeme u nás. Mullis a kol. (2004, s. 3) vnímají čtenářskou gramotnost jako „schopnost rozumět formám psaného jazyka, které vyžaduje společnost nebo oceňují jednotlivci, a tyto formy používat" (blíže viz kapitola 3 této studie). V kontextu českého kurikula se v posledních letech v didaktice literární výchovy začalo užívat termínu čtenářská kompetence, dle Kulkova pojetí (1990, cit. podle Lederbuchové, 2004) se jí rozumí „celková, především dlouhodobě utvářená připravenost $\mathrm{k}$ četbě, do níž se promítají i čtenářské zájmy a potřeby“. Termín čtení je dle Trávníčka (2008, s. 35) „mediální aktivita zaměřená na knihy a jejich duševní přisvojování; čas věnovaný knihám; základní aktivita související s knihami a socio-kulturní dovednost (gramotnost)“. Liptáková a kol. (2011, s. 453) zdůrazňují, že čtení lze také pokládat za proces přijímání informací, který mj. sestává z fáze interpretačně-hodnotící či responsní (znovuprožívání a dotváření smyslu v představách).

5 Proces začleňování standardů do kurikula ve Spojených státech amerických je poměrně zdlouhavý a sestává z více fází, mj. z (a) tvorby počáteční rámcové osnovy: „curriculum framework“, (b) monitorování, (c) testování ve školách atd. (viz Anderson et al., 1996). 
Autoři (NGA Center \& CCSSO, 2015) se pomocí kurikulárního dokumentu snaží reagovat na stagnaci vývoje vzdělávání ve Spojených státech amerických, kdy jako země v oblasti vzdělávání ztratila tzv. „pevnou půdu pod nohama" v porovnání s jinými zeměmi podobné úrovně.

Učitelé měli ve vývoji CCSS klíčové postavení. Jako členové různých týmů poskytovali zpětnou vazbu a zasílali připomínky skrze nejrůznější organizace spolupracující na př́ípavě finální verze dokumentu. Celkový počet zapojených států USA v roce 2014 čítal čtyřicet tři, $\mathrm{k}$ nim náležel distrikt Kolumbie (District of Columbia), vzdělávací aktivity ministerstva obrany (The Department of Defense Education Activity), ostrov Guam, Americká Samoa, Havaj, Severní Mariánské ostrovy a Americké Panenské ostrovy, které jsou v současnosti v procesu lokální implementace standardů.

\section{$1 \quad$ Pojetí Standardů společného základu}

Následující podkapitola představuje obsah dokumentu CCSS. V porovnání s platným českým kurikulem (Rámcové vzdělávací programy; dále jen RVP), který poskytuje rámcovou oporu pro všechny vyučované předměty daného stupně vzdělávání, jsou Standardy společného základu vytvořeny pouze pro dvě vzdělávací oblasti základní a střední školy, a to: (a) standardy pro vzdělávací oblast anglický jazyk (English language arts \& literacy standards), (b) matematické standardy (Mathematics standards).

Ve Spojených státech amerických jsou vytvořeny standardy také pro další vzdělávací oblasti. Např. pro výuku zeměpisu mohou poskytnout oporu standardy koncipované v publikaci Geography for life: National geography standards (dále jen NGS; Heffron \& Downs, 2012). Ty byly stejně jako Standardy společného základu navrženy tak, aby učitelé jasně porozuměli tomu, co vše by žáci měli obsáhnout v průběhu školní docházky a pomohli jim mj. také rozvíjet prŕrodovědnou gramotnost. NGS (viz NCGE, 2015) odkazují na propojení se Standardy společného základu, které od šestého do dvanáctého ročníku (Grade 6-12) věnují svou pozornost rozvoji gramotnosti v historických, společenských, přírodovědných a technických předmětech (Literacy in history/social studies, science, and technical subjects).

Samotná koncepce Standardů společného základu je založena na jejich implementaci od nejnižších ročníků základní školy až po školu střední $\left(K-12^{6}\right)$.

6 Od předškolní př́ípravy až po dvanáctý ročník v rámci střední školy $(K-12$; Kindergarten Grade 12). 
Důvodem je zřejmá návaznost jednotlivých očekávaných výstupů na konci každého ročníku. ${ }^{7}$

Ačkoli standardy poskytují seznam očekávaných výstupů za daný ročník, nedefinují, jak by měly být učitelem chápány a vyučovány či jaké materiály by měly být použity pro jejich úspěšné dosažení. Školám a učitelům je dán individuální prostor, jak danou problematiku uchopit, v důsledku čehož může ale docházet k subjektivnímu chápání jednotlivých výstupů, a někteří učitelé by tedy mohli ocenit oporu ve formě návodných textů a zásobníku inspirací. Př́lohy Standardů společného základu ELA Appendices (viz dále kapitola 2) tomuto problému částečně předchází.

Standardy společného základu kladou vysoké nároky na úzkou spolupráci školy s rodinou a na postupný a cílený individuální rozvoj daného žáka. Nejinak je tomu u Standardů společného základu pro vzdělávací oblast anglický jazyk, kterými se blíže zabýváme v následující části příspěvku.

\section{$2 \quad$ Standardy pro vzdělávací oblast anglický jazyk}

Tato podkapitola je věnována vymezení Standardů společného základu v oblasti anglického jazyka a pojetí gramotnosti postupujícího napříc školním vzděláváním. Autorka je nejdříve představuje z širšího pohledu (od předškolní výuky do dvanáctého ročníku; $K-12$ ), seznamuje s obsahem a strukturou kurikulárního dokumentu a poté se $\mathrm{v}$ další podkapitole hlouběji zabývá výukou čtení ${ }^{8}$ napříč celou primární školou (elementary school) a dále speciálně v jejím čtvrtém ročníku. ${ }^{9}$

Standardy společného základu pro rozvoj gramotnosti ve vzdělávací oblasti anglického jazyka od šestého ročníku základní školy (Common core state standards for English language arts \& literacy) se neomezují pouze na výuku anglického jazyka jakožto vyučovacího předmětu, ale snaží se postihnout

Podobně jako v Rámcových vzdělávacích programech u nás za určité období.

B Výuku čtení pro potřeby této studie autorka chápe šířeji než jen jako proces nácviku správné techniky čtení a plynulého čtenářského projevu, k němuž dochází převážně v prvních dvou ročnících prvního stupně základní školy. $\mathrm{Z}$ důvodu propojení amerického a českého pojetí vzdělávání se autorka (vedle čtení informačních textů a základních dovedností čtení) soustředí na literární výuku.

9 Kapitola se blíže zaobírá čtvrtým ročníkem primární školy z důvodu orientace výzkumného vzorku autorčina výzkumu čtenářství na danou věkovou skupinu. 
celou šíři mezipředmětových vazeb $\mathrm{v}$ okruhu školního vzdělávání ${ }^{10}$ (NGA Center \& CCSSO, 2015), kdy:

[...] v rámci Standardů společného základu mají žáci číst př́íběhy, uměleckou literaturu i složité texty, které jim poskytnou fakta a základní vědomosti z oblastí, jako jsou př́rodověda a společenské vědy. Žákům budou kladeny takové otázky, aby byli nuceni odkazovat na to, co četli. Tato metoda prohloubí jejich schopnost kritického myšlení, analytického uvažování a schopnost řešit problémy, což jsou vlastnosti potřebné $\mathrm{k}$ úspěchu na vysoké škole, v budoucím zaměstnání i životě. (para. 2)

Standardy pro vzdělávací oblast anglický jazyk (English language arts standards) jsou koncipovány do několika oblastí: (1) části dle ročníků školního vzdělávání (od předškolních tříd až po dvanáctý ročník střední školy); (2) části, které se zaměřují na rozvoj určité dovednosti (čtení: literatura, texty informačního charakteru a základní dovednosti čtení, psaní, mluvení, poslech a řečové dovednosti) ${ }^{11}$; (3) část nabízející doplňující standard (Standard 10), který informuje např. o rozsahu, kvalitě a náročnosti textů, prezentuje zastoupení literárních žánrů, tematické propojení textů apod.; ${ }^{12}$ (4) část přinášející pohled na gramotnostní pojetí historických, společenských a technických předmětů v šestém až dvanáctém ročníku studia (history/social studies; science and technical subjects; writing); (5) př́lohy (ELA; English language arts appendices) prezentující terminologickou základnu podpořenou aktuálními výzkumy, bohatý zásobník literárních a informačních textů a praktické př́klady studentského psaní (ukázky slohových prací).

Každý oddíl Standardů pro vzdělávací oblast anglický jazyk je opatřen instrukcemi, jak jej chápat, stručnou charakteristikou konkrétního stupně vzdělávání se stěžejními cíli a formulovanými výstupy pro jednotlivý ročník. Členění je přehledné a logicky uspořádané (viz NGA Center \& CCSSO, 2015).

Ve srovnání s Rámcovým vzdělávacím programem ZV (VÚP, 2013; dále jen RVP $Z V$ ), kde jsou výstupy orientovány podle vzdělávací oblasti Jazyk a jazyková komunikace (komunikační a slohová výchova, jazyková a literární výchova), tyto standardy poskytují detailnější a komplexnější pohled na problematiku

10 V 6.-12. ročníku jsou to předměty jako historie/společenské vědy či technické předměty.

11 V originálním znění (NGA Center \& CCSSO, 2015) - Reading: literature; Reading: informational text; reading: foundational skills; writing; speaking and listening; language.

12 Více informací o Standardu 10 viz Appendix A: Research supporting key elements of the standards glossary of key terms (NGA Center \& CCSSO, 2015). 
výuky jazyka. Nový rozměr představuje zejména rozdělení výstupů z oblasti výuky čtení podle typu textového materiálu (čtení literárního textu, čtení textu informačního charakteru), a to v celé šíri vzdělávání od předškolních tříd až po ukončení střední školy s cílem rozvíjet gramotnosti žáků. ${ }^{13}$ Právě výukou čtení se více zaobíráme v následující podkapitole (viz kap. 2.1).

\subsection{Výuka čtení napříč školním vzděláváním K-12}

Kurikulární dokument CCSS věnuje prostor výuce čtení ve třech různých složkách: (1) čtení: literatura; (2) čtení: informační text; (3) čtení: základní dovednosti, a to od předškolního vzdělávání do dvanáctého ročníku střední školy $(K-12)$. Pro podporu standardů těchto konkrétních oblastí CCSS prezentuje také Základní standardy čtení k př́pravě na vysokoškolské studium a na budoucí zaměstnání (College and career-readiness anchor standards for reading), které definují, čemu všemu by žáci měli být schopni rozumět a co vše by měli zvládnout a prokázat na konci dvanáctého ročníku (viz tabulka 1).

Autoři (NGA Center \& CCSSO, 2010) zdůrazňují nutnost kvalitní četby - jak literární, tak i informační povahy - pro vysokoškolskou a profesní připravenost. Díky čtení uměleckých textů rozličných literárních žánrů (drama, poezie, próza aj.) z různých časových období a koutů světa se studentům prohloubí kulturní a literární povědomí. Čtení informačních, vědeckých a historických textů jim zase pomůže vytvořit a rozšírit si znalosti z odlišných oblastí vzdělávání. Úkolem kurikulárního dokumentu je pak záměrně a strukturovaně rozvíjet obsah znalostí těchto oblastí v jednotlivých ročnících studia.

Následující tabulka (tabulka 1) prezentuje strukturu Základních standardů čtení k př́pravě na vysokoškolské studium a na budoucí zaměstnání, které jsou rozděleny do několika okruhů: (a) klíčové ideje a podrobnosti; (b) umění a struktura; (c) integrace znalostí a myšlenek; (d) rozsah čtených textů a úroveň složitosti textu. Každému z nich je věnován soupis výstupů, kterých by žáci měli být schopni dosáhnout v průběhu školní docházky.

$13 \mathrm{~V} R V P Z V$ jsou čtenářské dovednosti jedním $\mathrm{z}$ bodů učiva a současně nástrojem vzdělávacích oblastí a též klíčových kompetencí. 


\section{Tabulka 1 \\ Základní standardy čtení $k$ prrípravě na vysokoškolské studium a budoucí zaměstnání}

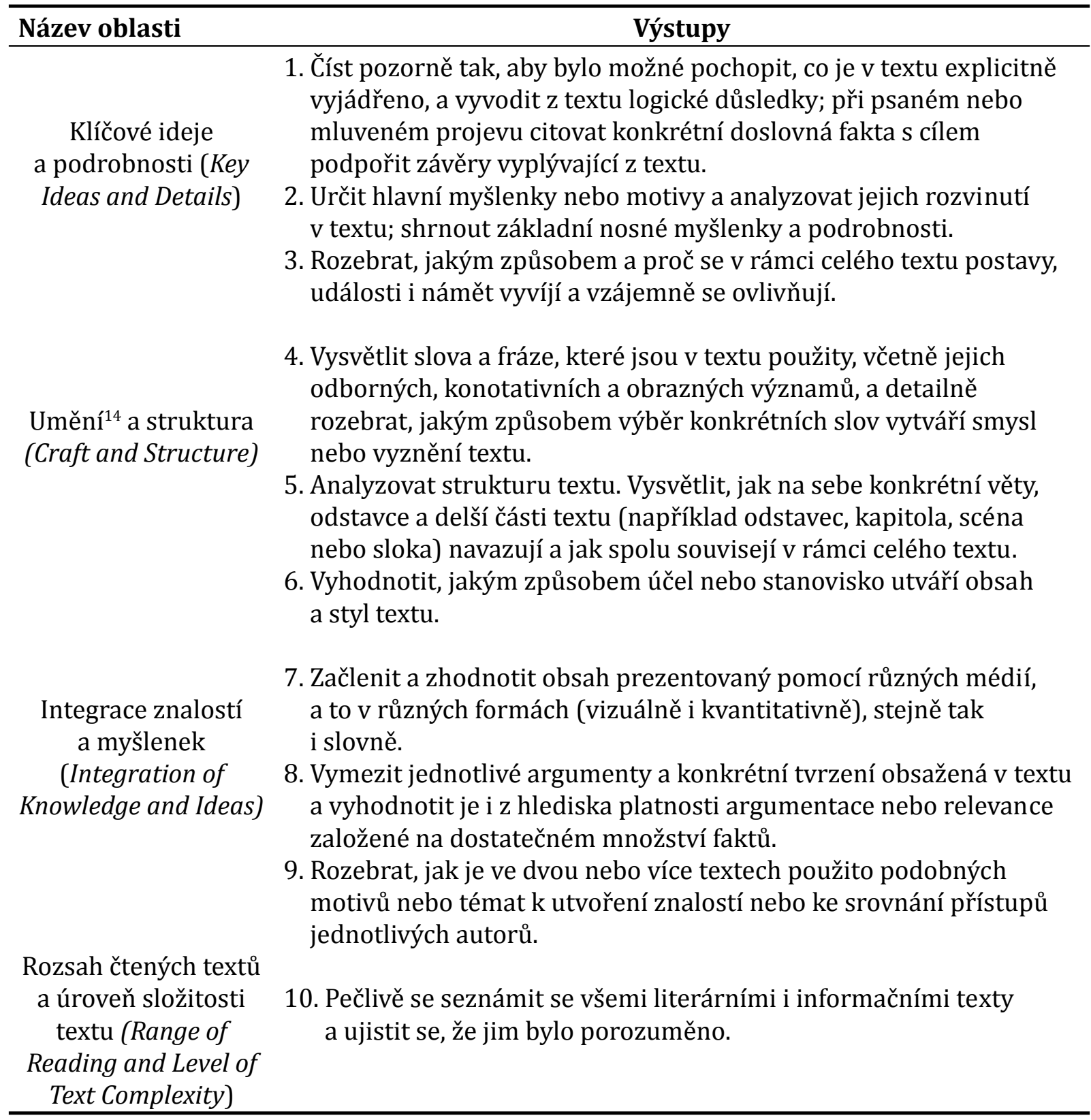

Pozn. Přeloženo autorkou z originálního názvu College and career-readiness anchor standards for reading dle NGA Center a CCSSO (2010, s. 10).

14 Přeloženo v kontextu chápání čtenářské kompetence, podle níž by mj. měl „„̌ák získat základním vzděláním schopnost číst věcnou, publicistickou, ale hlavně uměleckou literaturu, jeho dovednost číst by se měla kultivovat ve schopnost četby, tj. schopnost komunikace s uměleckým literárním dílem“ (Lederbuchová, 2010, s. 13). 
České Rámcové vzdělávací programy žádný takový dokument, jenž by představoval celkové výstupy výuky čtení pro školní vzdělávání, nenabízí. Pro výuku čtení jich lze však několik nalézt podle rozdělení do daných období (první a druhé období). V RVP ZV (VÚP, 2013) jsou např. prezentovány ve vzdělávací oblasti Jazyk a jazyková komunikace v oboru Český jazyk a literatura na prvním stupni ZŠ, ve složce Komunikační a slohová výuka:

První období: plynule čte s porozuměním texty přiměřeného rozsahu a náročnosti; porozumí písemným nebo mluveným pokynům přiměřené složitosti. Druhé období: čte s porozuměním přiměřeně náročné texty potichu i nahlas; rozlišuje podstatné a okrajové informace $\mathrm{v}$ textu vhodném pro daný věk; podstatné informace zaznamenává, posuzuje úplnost či neúplnost jednoduchého sdělení; reprodukuje obsah přiměřeně složitého sdělení a zapamatuje si z něj podstatná fakta. (s. 18)

Pro druhý stupeň základní školy v RVP ZV (VÚP, 2013) výstupy týkající se rozvoje čtení s porozuměním, čtenářských schopností a čtenářské (a literární) gramotnosti najdeme ve vzdělávacích oblastech Jazyková výchova, Literární výchova a Komunikační a slohová výchova. Na gymnáziích se pak objevují zmínky ve vzdělávacím oboru Český jazyk a literatura (viz VÚP, 2010).

Vzhledem k zaměření výzkumu autorky na výuku čtení v primárním vzdělávání se v př́spěvku soustřed'ujeme především na standardy zacílené na první až pátý ročník primární školy (elementary school) označované pod zkratkou K-5 (Kindergarten-Grade 5). Konkrétně se jedná o první oblast Standardů společného základu pro vzdělávací oblast anglický jazyk koncipovanou pod názvem Předškolní výuka - dvanáctý ročník střední školy (KindergartenGrade 12).

\subsection{Vymezení základních dovedností čtení, zastoupení uměleckého textu a textu informačního charakteru na prvním stupni základní školy}

Jak již bylo prezentováno v předchozích podkapitolách, Standardy společného základu definují souhrn výstupů žáka za daný školní rok pro rozvoj základních dovedností čtení a pro oblast čtení literárních a informačních textů. Tyto výstupy jsou mj. sestaveny pro žáky od nejnižších ročníků (od předškolního, tzv. nultého ročníku vzdělávání; kindergarten) až po pátý ročník základní školy. Nejdř́ve se souhrnně seznámíme s výstupy pro první čtyři ročníky $(K-3)$, a poté poskytneme detailnější pohled na čtvrtý ročník primárního 
vzdělávání a jeho obsah standardů pro výuku čtení v jednotlivých vzdělávacích oborech.

V CCSS je v rámci primárního vzdělávání (elementary school) na začátku vzdělávacího oboru čtení (reading) stručné představení koncepce, v níž se od žáků očekává úspěšné splnění výstupů pro konkrétní složky tohoto oboru: (a) čtení: literatura (reading: literature); (b) čtení: informační text (reading: informational text) - naplnění standardů specifických pro daný ročník s cílem rozvíjet čtení s porozuměním; (c) zvládnutí oblasti: základní čtecí dovednosti (foundational skills), které jsou určeny k rozvoji zdatného čtenáře s kapacitou pochopit texty různých typů a oborů (NGA Center \& CCSSO, 2010).

Ve Standardech společného základu (viz NGA Center \& CCSSO, 2010) zacílených na čtení literárních textů (čtení: literatura) se výstupy napříc prvním stupněm ZŠ zaměřují především na seznámení s uměleckými texty a klade se v nich důraz např. na rozšiřování slovní zásoby prostřednictvím čtených textů, rozpoznávání základních literárních žánrů (vyprávění, báseň), na popis, jak některá slova a fráze (aliterace, rým, opakující se výrazy aj.) dodávají rytmus textu (básni či písni) a smysl příběhu, vylíčení děje literárních textů umělecké povahy (včetně bajek, lidových příběhů, bájí a mýtů vycházejících z různých kultur) dle morálního poselství apod.

Výstupy pro složku čtení: informační text (viz NGA Center \& CCSSO, 2010) se soustřed'ují např. na pojmenování autora a ilustrátora díla, kladení otázek opírajících se o klíčové detaily textu, na popis ústředního motivu textu a jeho propojení mezi různými událostmi, užití ilustrací k popisu klíčových detailů apod. Výstupy jsou obohaceny např. o schopnost propojit text v historických souvislostech, určit hlavní účel textu (na co autor chce odpovědět), porovnat a dát do kontrastu stěžejní body obsažené ve dvou různých textech na stejné téma apod.

Do okruhu čtení: základní čtecí dovednosti autoři zakomponovali výstupy definované např̀ jako porozumění faktu, že mluvené slovo je zastoupeno v psaném jazyku specifickou sekvencí písmen a že slova jsou oddělena mezerami; žák by měl umět rozpoznat a pojmenovat všechna malá a velká písmena anglické abecedy; vymyslet slova, jež se navzájem rýmují apod.

V porovnání s $R V P Z V$ je v CCSS věnován větší prostor pro definování výstupů na konci školního roku ve všech třech složkách výuky čtení (literární a informační texty, základní dovednosti čtení). Standardy anglického jazyka pro 
výuku čtení ve čtvrtém ročníku základní školy (tabulka 2) poskytují detailnější pohled (v komparaci s RVP ZV) projevující se v rozdělení výstupů do definovaných složek výuky čtení. ${ }^{15}$

\section{Tabulka 2}

Standardy anglického jazyka pro výuku čtení ve čtvrtém ročníku primární školy

\begin{tabular}{|c|c|}
\hline Oblast čtení & Výstupy \\
\hline $\begin{array}{c}\text { Čtení: literatura } \\
\text { (Reading: Literature) }\end{array}$ & 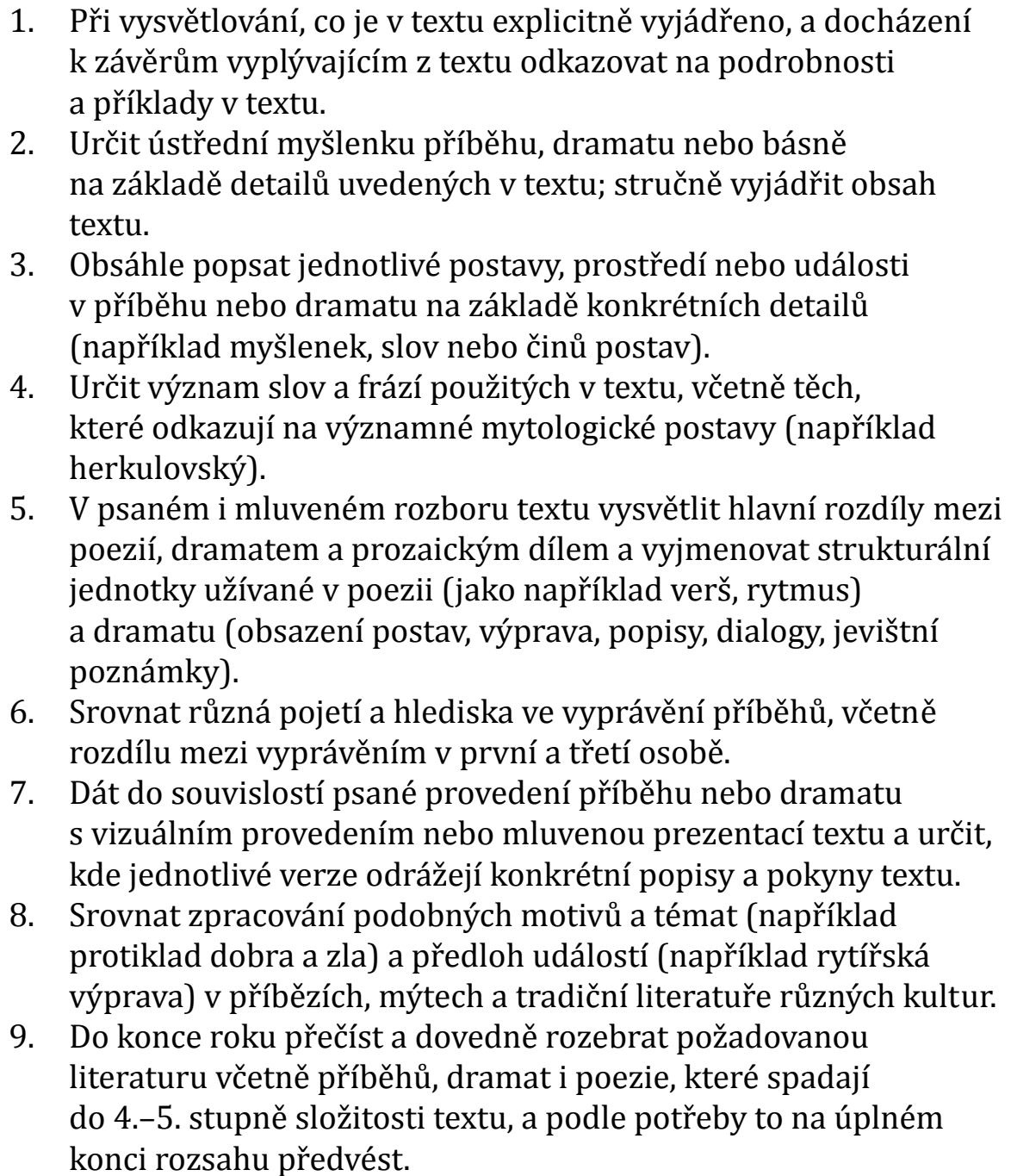 \\
\hline
\end{tabular}

15 V originálním dokumentu jsou složky výuky čtení členěny ještě do podkategorií (viz NGA Center \& CCSSO, 2010, s. 11-16), přičemž např. pro složku čtení: literatura jsou to: (a) klíčové ideje a podrobnosti (key ideas and details), výstupy 1-3; (b) umění a struktura (craft and structure), výstupy 4-6; (c) integrace znalostí a myšlenek (integration of knowledge and ideas), výstupy 7 a 8; (d) rozsah čtených textů a úroveň složitosti textu (range of reading and level of the text complexity), výstup 9. 


\begin{tabular}{|c|c|}
\hline Oblast čtení & Výstupy \\
\hline $\begin{array}{c}\text { Čtení: základní } \\
\text { dovednosti } \\
\text { (Reading: } \\
\text { Foundational skills) }\end{array}$ & $\begin{array}{l}\text { 1. Využít znalosti o přiřazeních všech písmen, zákonitostech } \\
\text { tvoření slabik a morfologii (např́klad kořen, předpona a přípona } \\
\text { slova) k přečtení neznámých mnohoslabičných slov v kontextu } \\
\text { i mimo kontext. } \\
\text { 2. Číst přesně a plynule tak, aby bylo možné pochopit text. } \\
\text { 3. Číst text na jednotlivých úrovních účelně a s porozuměním. } \\
\text { 4. Číst prózu a poezii na jednotlivých úrovních nahlas, přesně, } \\
\text { výrazně a vhodným tempem. } \\
\text { 5. Využít kontext k potvrzení nebo opravení se při posouzení } \\
\text { a pochopení slov, v případě potřeby text znovu přečíst. }\end{array}$ \\
\hline $\begin{array}{l}\text { Čtení: informační text } \\
\text { (Reading: } \\
\text { Informational text) }\end{array}$ & $\begin{array}{l}\text { 1. Při vysvětlování, co je v textu explicitně vyjádřeno, a při } \\
\text { vykreslování, co z textu plyne, odkazovat na podrobnosti } \\
\text { a př́klady v textu. } \\
\text { 2. Určit hlavní myšlenku textu a vysvětlit, jak klíčové detaily tuto } \\
\text { myšlenku podporují; shrnout obsah textu. } \\
\text { 3. Rozebrat události, postupy, myšlenky nebo pojetí v historických, } \\
\text { vědeckých nebo technických textech a na základě konkrétních } \\
\text { informací v textu vysvětlit, co se stalo a proč. } \\
\text { 4. Určit význam obecných vědeckých a konkrétních slov nebo frází } \\
\text { z určitého oboru v textu týkajícím se stupně } 4 \text { - téma nebo oblast } \\
\text { předmětu. } \\
\text { 5. Popsat celou výstavbu (například chronologii, porovnání, } \\
\text { příčinu/výsledek, problém/vyřešení) událostí, myšlenek, pojetí } \\
\text { nebo informací v celém textu nebo v jeho části. } \\
\text { 6. Porovnat přímý (vyplývající z textu) a nepřímý význam stejné } \\
\text { události nebo tématu; popsat rozdíly v hledisku a poskytnutých } \\
\text { informacích. } \\
\text { 7. Interpretovat informace předvedené vizuálně, ústně nebo } \\
\text { kvantitativně (např́klad v tabulkách, grafech, schématech, } \\
\text { časových liniích, animacích nebo interaktivních prvcích } \\
\text { webových stránek) a vysvětlit, jak informace napomáhají } \\
\text { k pochopení textu, ve kterém se vyskytují. } \\
\text { 8. Vysvětlit způsob, jakým autor použivá zdůvodnění a fakta, aby } \\
\text { podpořil určité body v textu. } \\
\text { 9by bylo možné psát nebo přednášet o předmětu informovaně, } \\
\text { spojit informace ze dvou textů se stejným tématem. } \\
\text { 10. Do konce roku přečíst a dovedně rozebrat shromážděné } \\
\text { informační texty, včetně textů vědeckých, technických a textů } \\
\text { z oboru historických a sociálních studií, které spadají } \\
\text { do 4.-5. stupně složitosti textu podle potřeby horní hranice } \\
\text { vymezení (výstupy platné pro daný ročník). }\end{array}$ \\
\hline
\end{tabular}

Pozn. Přeloženo a upraveno autorkou podle NGA Center a CCSSO (2010, s. 11-16). 
Jak je patrné (tabulka 2), ve Standardech společného základu je považováno za důležité pojmout celkem tři složky výuky čtení. Čtení textů umělecké povahy v nich také zaujímá své místo. Ačkoli v českém edukačním prostředí jsou texty umělecké povahy samozrrejmou součástí výuky, kurikulární dokument $R V P Z V$ estetickovýchovnou složku těchto textů plně neakceptuje ${ }^{16}$ (viz dále; srov. Hník, 2010; Lavičková, 2014). Standardy společného základu se snaží zakomponovat tuto složku do výuky prostřednictvím sepsaných výstupů (čtení: literatura). Poskytují také možnost podívat se na míru doporučeného zastoupení textů literárních a textů informačního charakteru ve výuce čtení napříč celým školním vzděláváním $(K-12$, viz NGA Center \& CCSSO, 2010).

Duke, Halladay a Roberts (2013, s. 44) se nad rozložením obou typů textů zamýšlejí. Podle nich by bylo mylné se domnívat, že CCSS zcela podporují texty informační a že umělecké texty jdou stranou. Doporučené zastoupení různých typů textů prezentované ve Standardech společného základu pro čtvrtý ročník prvního stupně základní školy ukazuje, že by literární umělecké texty měly při výuce čtení zaujímat až $50 \%$ čtených materiálů, v osmém ročníku je to pak $45 \%$. A zatímco podle Duka a kol. (2013, s. 45) v USA existují standardy, které separují oba typy textových materiálů a výuka probíhá odděleně, CCSS poskytují učitelům prostor vyučovat napříč standardy a literárními žánry. Např́íklad právě standardy zacílené na první stupeň $(K-5)$ pro výuku čtení uměleckých a informačních textů se soustřed'ují na tematické propojení textů s důrazem na procvičení a obohacení slovní zásoby žáka.

\section{Několik „postřehů“ k rozdílnosti amerického a českého kurikula v pojetí výuky čtení a literární výchovy}

Jak bylo naznačeno $\mathrm{v}$ předchozích částech kapitoly, kurikulární dokumenty CCSS a RVP (jak pro základní školy, gymnázia i střední školy) se v mnoha ohledech liší. S přihlédnutím k rozdílným kulturám, tradicím i socio-ekonomickým faktorům lze na některé odlišnosti upozornit. ${ }^{17}$

Ačkoli oba kurikulární dokumenty vycházejí z požadavku rozvíjení gramotnosti naprríč školním vzděláváním, $R V P$ některé její aspekty nerozpracovává. Konkrétně se nap̌r. jedná o rozvoj čtenářské gramotnosti, ve které dle

16 To bude pravděpodobně důvodem, proč je funkce mimoestetická v českém pojetí čtenářské gramotnosti vyzdvihována $v$ RVP nad estetickou funkcí.

17 O problematice českého kurikula a kurikulární reformy viz např. Janík (2013), Janík a kol. (2011), Maňák (2007), Spilková (2005), Štech (2013). 
českého pojetí není zcela zmíněna estetickovýchovná složka literárního vzdělávání a naopak ve znění českého kurikula je vyzdvihována pragmatická funkce textu (srov. Hník, 2010; Lavičková, 2014; Liptáková et al., 2011). ${ }^{18}$ Tento nedostatek lze dávat do souvislosti se samotným překládáním a chápáním pojmu čtenářská gramotnost, který je u nás v souvislosti s realizací mezinárodního šetření PISA (Palečková \& Tomášek, 2005, s. 37) charakterizován jako „schopnost jedince porozumět psanému textu, přemýšlet o něm a používat jej k dosahování určitých cílů, k rozvoji vlastních schopností a vědomostí a k aktivnímu začlenění do života společnosti“.

V posledních letech se u nás ale začínají projevovat tendence v definování dílčích oblastí čtenářské gramotnosti, kdy např. Šlapal a kol. (2012, s. 10) rozšiřují chápání tohoto pojmu o to, že „čtenářská gramotnost je celoživotně se rozvíjející vybavenost člověka vědomostmi, dovednostmi, schopnostmi, postoji a hodnotami potřebnými pro užívání všech druhů textů v různých individuálních i sociálních kontextech". Do těchto rovin se dle autorů vedle metakognice, vysuzování atd., promítá mimo jiné také vztah ke čtení (čtenářství). V souvislosti s rozšířením tohoto termínu o estetický rozměr se projevuje i snaha o zavedení zcela nového pojmu literární gramotnost (srov. Zítková, 2004a; Lavičková, 2014), který by měl rozvíjet estetickovýchovný potenciál literárního vzdělávání. To bylo u nás v didaktice literární výchovy podpořeno literárněvědním bádáním již od počátku dvacátého století (Mukařovský, $1925)^{19}$ a je s podivem, že $R V P$, které by měly odpovídat tradicím české školy, tento fakt zcela neakceptují, a to ani přesto, že výuka čtení v českém prostředí se vždy opírala o čtení uměleckých textů z čítanek či o povinnou literaturu $\mathrm{v}$ podobě beletristických děl.

Literární vzdělávání klade důraz na komunikační pojetí literární výchovy, pro něž je právě „specifický estetickovýchovný proces formování kultivovaného dětského čtenáře" (Lavičková, 2014, s. 23). Ačkoli tomu tak je, současná podoba literárního vyučování v našich školách, odvíjející se od platného kurikula, se soustředí spíše na literárněvědné a historicko-biografické znalosti a na frontálně vedený výklad učitele na úkor přímé interakce žáka s uměleckým textem.

V dokumentu Standardy pro základní vzdělávání - Český jazyk a literatura (Klímová et al., 2013) zpracovaného dle upraveného RVP ZV (VÚP, 2013) si

18 Oproti Standardům společného základu, ve kterých zaujímá čtenářská gramotnost své místo a funkci napříč ročníky, v RVP ZV není důraz na její rozvoj dostatečný a nefiguruje jako významný cíl na žádné úrovni (VÚP, 2011, s. 17).

19 A později též v dalších výzkumech (Chaloupka, 1982; Lederbuchová, 2004, 2010). 
lze povšimnout bodů, které částečně eliminují výše uvedené problémy vyskytující se v současném literárním vzdělávání u nás. Ty se odráží především ve formě ilustrativních úloh a indikátorů očekávaných výstupů $R V P Z V$, které jsou pro pátý ročník primární školy v oblasti tematického okruhu literární výchova (Klímová et al., 2013, s. 23) formulovány tak, že žák mj. řekne, „jak na něj vyslechnutá/přečtená ukázka působí a jaký v něm vyvolala dojem“. Podobně se též profiluje očekávaný výstup pro devátý ročník v rámci literární výchovy: „Žák formuluje ústně i písemně dojmy ze své četby, návštěvy divadelního nebo filmového představení a názory na umělecké dílo" (Klímová et al., 2013, s. 48).

Americký kurikulární dokument CCSS estetickou složku literárního díla př́ímo nevyzdvihuje, oproti $R V P Z V$ ale přináší detailnější pohled na rozdělení výuky čtení do tří oblastí, přičemž jedna z nich je právě zaměřena na čtení literárních textů (tabulka 2), a prezentuje také procentuální zastoupení informačních a literárních textů napříč celým školním vzděláváním. Je tedy zřejmé, že autoři CCSS respektovali jak informačně laděné texty s těžištěm v jejich pragmatickém využití, tak i estetickou složku literárních děl. Takto vytvořený koncept rozdělení je věnován každému ročníku zvlášt', a tudíž poskytuje větší prostor pro formulaci očekávaných výstupů za dané období. Pro celý první stupeň $(K-5)$ je takových očekávaných výstupů v CCSS pro literární vzdělávání okolo čtyřiceti pěti a velká část z nich je zacílena na hodnocení literárního textu a pochopení jeho smyslu.

V platném českém kurikulu se složka Literární výchovy základní školy omezuje pouze na osm očekáváných výstupů (dohromady pro první a druhé období), přičemž procesu recepce a interpretaci literárního textu je v RVP ZV (VÚP, 2013) prostor věnován minimálně a nejvíce se mu přibližují formulace očekávaných výstupů na konci prvního období: „Pracuje tvořivě s literárním textem podle pokynů učitele a podle svých schopností", a na konci období druhého: „Při jednoduchém rozboru literárních textů používá elementární literární pojmy" (VÚP, 2013, s. 20). Detailnější popis toho, co je pod zmíněnou „tvořivou prací doopravdy zamýšleno, s interpretací nepočítá, a „tvořivá práce s literárním textem" je v dokumentu omezována pouze na: (a) přednes literárních textů, (b) volnou reprodukci přečteného či slyšeného textu, (c) dramatizaci, (d) vlastní výtvarný doprovod (VÚP, 2013, s. 20). Na tomto místě však vyvstává otázka, jaké úrovně v procesu recepce literárního textu jsou mladší žáci schopni za dané období dosáhnout, a zda tedy mohou úspěšně provést alespoň elementární interpretaci textu (viz Chaloupka, 1982). Např. Zítková (2004b, s. 5) ale ve výuce literaturou na prvním stupni základní 
školy zdůrazňuje důležitost právě oné literárněvýchovné interpretace textu, tudíž lze první tvořivé pokusy na prvním stupni považovat za jakési stavební kameny této práce s literárním textem. RVP ZV (VÚP, 2013, s. 16) v úvodu dokumentu avizuje, že žáci v prủběhu školní docházky „postupně získávají a rozvíjejí čtenářské návyky i schopnosti tvořivé recepce, interpretace a produkce literárního textu“. Jakým způsobem a v jaké návaznosti by k tomu měli dospět, formulované očekávané výstupy neuvádějí.

V souvislosti s problematikou výuky čtení lze jako přínosné a praktické hodnotit poskytnutí seznamu literárního kánonu jako př́lohu ke Standardům pro vzdělávací oblast anglický jazyk, který učiteli umožní propojit a srovnat mezi sebou různé druhy textových materiálů a možnost nahlížet na dané téma $\mathrm{z}$ více perspektiv. Žáci mohou v konkrétních textech hledat spojující prvky, vyjádřit a srovnat pocity, které $v$ nich byly po přečtení vyvolány či se zamýšlet nad společnými a odlišnými znaky různých literárních žánrů.

Další rozdílnost porovnávaných kurikul (tabulka 3) je spatřována v prezentaci souhrnných standardů výuky čtení k př́ípravě na vysokoškolské studium a na budoucí zaměstnání. Protože středoškolské vzdělání v našem prostředí neodpovídá jednotnému americkému pojetí (high school), české kurikulum přináší v návaznosti na předškolní a základní vzdělávání Rámcové vzdělávací programy také pro (a) gymnázia a (b) střední odborné vzdělávání.

Tabulka 3

Některé rozdílnosti amerického a českého kurikula v pojetí výuky čtení a literární výchovy

\begin{tabular}{lll}
\hline & $\begin{array}{c}\text { Rámcový vzdělávací program } \\
\text { ZV }\end{array}$ & $\begin{array}{c}\text { Standardy společného } \\
\text { základu }\end{array}$ \\
\hline Koncepce dokumentu & $\begin{array}{l}\text { RVP pro každý stupeň a úroveň } \\
\text { vzdělávání zvlášt'. } R V P Z V \text { pro } \\
\text { první a druhý stupeň základní } \\
\text { školy dohromady (ročník 1.-9.) }\end{array}$ & $\begin{array}{l}\text { Od předškolní výuky } \\
\text { po dvanáctý ročník }(K-12)\end{array}$ \\
$\begin{array}{lll}\text { Očekávané výstupy výuky } \\
\text { čtení a literární výchovy }\end{array}$ & $\begin{array}{l}\text { V } R V P Z V \text { pouze osm výstupů } \\
\text { (dohromady pro první a druhé } \\
\text { období) }\end{array}$ & $\begin{array}{l}\text { Pro první stupeň }(K-5) \\
\text { celkem čtyřicet pět výstupů }\end{array}$ \\
$\begin{array}{l}\text { Respektování estetické složky } \\
\text { literárních děl }\end{array}$ & $\begin{array}{l}\text { Vyzdvihování pragmatické } \\
\text { funkce nad estetickou funkcí }\end{array}$ & $\begin{array}{l}\text { Respektování vyváženého } \\
\text { rozložení informačních } \\
\text { a literárních textů ve výuce }\end{array}$ \\
$\begin{array}{l}\text { Př́loha jako podpůrný } \\
\text { materiál pro práci ve výuce } \\
\text { čtení a literární výchovy }\end{array}$ & Bez přílohy & $\begin{array}{l}\text { Literární kánon podporující } \\
\text { práci s literárním textem } \\
\text { z více perspektiv }\end{array}$ \\
\hline
\end{tabular}


Obě porovnávaná kurikula poskytují soupis očekávaných výstupů a lze u nich předpokládat jejich vzájemnou propojenost za konkrétní vzdělávací období $\mathrm{s}$ možností sledovat zvyšující se nároky s postupujícími ročníky až k úspěšnému absolvování školní docházky.

\section{$4 \quad$ Závěr}

Standardy společného základu mají mezi odborníky z řad školního prostředí mnoho příznivců i odpůrců, což je typické pro každou kurikulární změnu v jakémkoli prostředí a čase. Autoři (NGA Center \& CCSSO, 2015) se ale snaží poskytnout bohatou základnu informací tak, aby učitelé, ale i veřejnost, byli schopni pochopit základní principy předkládaných standardů.

V naší studii jsme se snažili představit kurikulární dokument Standardy společného základu, které byly do roku 2014 přijaty většinou států Spojených států amerických. Od nastínění pozadí vývoje a implementace těchto standardů jsme se blíže soustředili na analýzu standardů pro vzdělávací oblast anglický jazyk se zaměřením na výstupy jednotlivých ročníků koncipovaných pro výuku čtení s detailnějším pohledem na čtvrtý ročník prvního stupně základní školy.

Autoři Standardů společného základu (NGA Center \& CCSSO, 2010) v okruhu výuky čtení zdůrazňují nutnost kvalitní četby, která by se měla opírat jak o texty umělecké, tak i informační. Taková výuka čtení by neměla separovat oba typy textových materiálů, ale měla by poskytnout učitelům prostor vyučovat napříč literárními žánry.

Na základě analýzy pojetí výuky čtení na základní škole vycházející ze Standardů společného základu jsme se vyjádřili k některým rozdílnostem mezi výše zmíněným kurikulárním dokumentem a RVP ZV (kapitola 3). I přesto, že obě kurikula vycházejí z různých kultur, na něž se zákonitě váží i rozličné socio-ekonomické faktory a tradice školního vyučování, upozornili jsme na některé odlišnosti v chápání výuky čtení. Ty se projevují např̀ v tom, že současný český kurikulární dokument oproti americkému plně neakceptuje estetickovýchovnou složku literárních děl a není v něm také zdůrazněn význam a smysl interpretačního přístupu v rámci literárněvýchovného procesu.

Jelikož si autorka v první řadě kladla za cíl prostřednictvím této studie představit Standardy společného základu české odborné veřejnosti, nevěnuje se komparativnímu pohledu obou kurikulí do hloubky. Do budoucna lze však příspěvek vnímat jako možné východisko pro další srovnávání. 


\section{Literatura}

Anderson, L., Fiester, L., Gonzales, M., \& Pechman, E. (1996). Standards. What are they? Dostupné z http://www.ed.gov/pubs/IASA/newsletters/standards/pt1.html

Duke, N. K., Halladay, J. L., \& Roberts, K. L. (2013). Reading standards for informational text. In L. M. Morrow, T. Shanahan, \& K. K. Wixson (Eds.), Teaching with the Common core standards for English language arts, preK-2 (s. 46-66). New York: Guilford Press.

Heffron, S. G., \& Downs, R. M. (2012). Geography for life: National geography standards. Geography education national implementation project. Washington: National council for geographical education.

Hník, O. (2010). Literární výchova: reflexe v oborové didaktice. In E. Príhodová (Ed.), Oborová didaktika $v$ príprave a d'alšom vzdělávání učitel materinského jazyka a literatúry (s. 152-158). Ružomberok: Katolicka univerzita v Ružomberku.

Chaloupka, O. (1982). Rozvoj dětského čtenářství. Praha: Albatros.

Janík, T. (2013). Od reformy kurikula k produktivní kultuře vyučování a učení. Pedagogická orientace, 23(5), 634-663.

Janík, T., Knecht, P., Najvar, P., Píšová, M., \& Slavík, J. (2011). Kurikulární reforma na gymnáziích: výzkumná zjištění a doporučení. Pedagogická orientace, 4(21), 375-415.

Klímová, K., Altmanová, J., Hájková, M., Hausenblas, O., Hoskovec, T., Kapustová, A., ... Vyskočil, M. (2013). Standardy pro základní vzdělávání. Český jazyk a literatura. Praha: MŠMT.

Lavičková, H. (2014). Umělecký text v didaktickém aparátu čítanek pro primární školu. Brno: Masarykova univerzita.

Lederbuchová, L. (2004). Dítě a kniha: o čtenářství jedenáctiletých. Plzeň: Vydavatelství a nakladatelství Aleš Čeněk.

Lederbuchová, L. (2010). Literatura ve škole. Plzeň: Západočeská univerzita v Plzni.

Liptáková, L.., Stanislavová, Z., Sičáková, L'., Hlebová, B., Kesselová, J., Klimovič, M., ... Rusňák, R. (2011). Integrovaná didaktika slovenského jazyka a literatúry pre primárne vzdelávanie. Prešov: Prešovská univerzita v Prešově.

Maňák, J. (2007). Kurikulum a hodnoty. Pedagogická orientace, 17(2), 2-10.

Mukařovský, J. (1925). Vyučování jazyku mateřskému na školách francouzských a o potřebě jeho reformy na našich školách. Střední škola, 5(18), 18-23.

Mullis, I. V. S., Kennedy, A. M., Martin, M. O., \& Sainsbury, M. (2004). Assesment framework and specifications. Progress in international reading literacy study. Chestnut Hill: Boston College.

NCGE. (2015). National council for geographic education. Dostupné z http://www.ncge.org/

NGA Center, \& CCSSO. (2010). Common core state standards for English language arts \& literacy in history/social studies, science, and technical subjects. Dostupné z http://www.corestandards. org/assets/CCSSI_ELA\%20Standards.pdf

NGA Center, \& CCSSO. (2015). Common core state standards initiative. Dostupné z http://www. corestandards.org/

NÚV. (2014). Společné základní standardy v USA. Standardy v ovládání anglického jazyka a v matematice. Zpravodaj - odborné vzdělávání v zahraničí, 25(3), 7.

Palečková, J., \& Tomášek, V. (2005). Učení pro zítřek: výsledky výzkumu OECD PISA 2003. Praha: ÚIV.

Rusek, M. (2015). Standardy základního vzdělávání pro výuku chemie. Pedagogika, 64(4), 422-428. 
Spilková, V. (2005). Rámcový vzdělávací program pro základní vzdělávání v kontextu transformace českého školství. Pedagogika, 55(1), 20-25.

Šlapal, M., Koštálová, H., \& Hausenblas, O. (Eds.). (2012). Metodika rozvoje čtenářství a čtenářské gramotnosti. Nový Jičín: KVIC.

Štech, S. (2013). Když je kurikulární reforma evidence-less. Pedagogická orientace, 23(5), 615-633.

Trávníček, J. (2008). Čteme? Obyvatelé České republiky a jejich vztah ke knize. Brno: Host.

VÚP. (2010). Rámcový vzdělávací program pro gymnázia. Praha: VÚP.

VÚP. (2011). Gramotnost ve vzdělání. Praha: VÚP.

VÚP. (2013). Rámcový vzdělávací program pro základní vzdělávání. Praha: VÚP.

Zítková, J. (2004a). Několik poznámek k literární komunikaci v primární škole. Brno: Masarykova univerzita.

Zítková, J. (2004b). Kapitoly z didaktiky literární výchovy ve 2.-5. ročníku základní školy. Brno: Masarykova univerzita.

\title{
Autorka
}

Mgr. Pavla Sýkorová, Masarykova univerzita, Pedagogická fakulta, Institut výzkumu školního vzdělávání, Poříčí 31, 60300 Brno, e-mail: 237409@mail.muni.cz

\section{Concept of the Common core state standards: Reading in elementary school}

\begin{abstract}
The aim of this study is to present the Common core state standards of the U.S. curriculum. The first parts detail the concept of the Common core state standards throughout the whole school education $(\mathrm{K}-12)$. The next passages are devoted to the analysis of the English language arts standards with a focus on reading in elementary schools and also relate these standards to the context of the current Czech curriculum, the Framework educational programme for basic education. The study suggests differences in the final outputs for teaching reading in elementary school. I found, for example, that, in contrast to the U.S. curriculum, the Czech curriculum does not fully incorporate aesthetic and educational literature components.
\end{abstract}

Keywords: Common core state standards, curriculum, teaching reading, Framework educational programme 